\title{
Ideje Komenského a výtvarná výchova
}

\author{
Petra ŠOBÁŇOVÁa
}

${ }^{a}$ Univerzita Palackého v Olomouci, Pedagogická fakulta, katedra výtvarné výchovy, Česká republika

\section{Úvod}

Cílem tohoto článku je poukázat na některé z množství inspirativních idejí Jana Amose Komenského a na jejich paralely s výzvami a aspekty současné výtvarné výchovy.

V roce 2020 uplynulo 350 let od úmrtí Jana Amose Komenského, v roce 2022 si připomeneme 430. výročí jeho narození. Při té př́iležitosti bude na různých odborných úrovních i mezi širokou veřejností oslavován Komenského odkaz, jistě budou zmiňovány známé teze jeho prací, jeho pohnutý osud, velkolepé didaktické dílo a nesmírný vliv na pedagogiku. Tím nejcennějším na všech připomínkách této osobnosti by ale bylo nejen opakování floskulí o „učiteli národư“, ale zejména nové čtení jeho díla a nové promýšlení klíčových idejí jeho pedagogického systému v kontextu současné situace „labyrintu světa a stavu našich srdcí“.

Snad budou oslavy výročí př́ležitostí také k „objevení“ duchovní dimenze Komenského díla a tento myslitel nebude nadále vnímán jen jako bystrý didaktik či nápaditý tvůrce objevných didaktických aplikací a geniálních učebnic, ale především jako dodnes inspirativní a naléhavý tvưrce komplexní odpovědi na otázku, co si počít ve světě, jak dát smysl působení a údělu člověka na světě - a jak na tuto archetypální otázku odpovídat v roli pedagoga nebo člověka zodpovědného za vzdělávací politiku.

\section{K duchovní dimenzi Komenského díla}

Tento článek usiluje - přes svůj omezený rozsah - o to zohlednit celou komplexitu Komenského myšlení; bude sice představeno jen několik vybraných motivů z Komenského díla, jde ale o motivy, jež při dnešní četbě Komenského spisů vedou k neodbytné komparaci se současným stavem praxe a pedagogického a oborově-didaktického myšlení.

Už jen sledování neuvěřitelné aktuálnosti Komenského myšlenek je fascinující, bylo by však př́lilš snadné selektivně vybírat jen to, co se nám právě hodí. Nelze opomíjet podstatu Komenského pedagogické koncepce, jíž je duchovní dimenze - at' již ji pojmenujeme jako vztahování se k Bohu, anebo obecněji jako transcendenci ve smyslu vztahování se k tomu, co nás přesahuje a co může být zdrojem onoho hledaného a unikavého smyslu života a věcí. (Druhé pojmenování je pro svou všeobecnost zřejmě výstižnější vzhledem k situaci člověka moderního či postmoderního; právě moderna a po ní ještě intenzivněji postmoderna totiž zproblematizovala univerzalitu jakéhokoliv náboženského systému, rozkolísala tradiční způsoby spirituality, zpochybnila existenci referenčního rámce v podobě Boha a univerzálně platného př́běhu o vykoupení; postmoderní pluralita nám neumožnuje redukování mnohosti 
cest $\mathrm{k}$ tomuto smyslu. $\mathrm{K}$ údělu současného člověka tak patří individuální zodpovědnost za hledání tohoto smyslu i svoboda ve způsobech jeho prožívání.)

Je třeba vracet se k této bázi Komenského filozofické a výchovné koncepce, již Komenský nabízí jako cestu k „nápravě věcí lidských“, - a chápat ji jako prostředek k překonání permanentní krize, v níž se postmoderní člověk - ochuzený o tuto podstatnou dimenzi života - nachází. Také dobově ukotvená snaha Komenského nabízet „všenápravu“ vycházela z vědomí společenské krize a jeho hluboká analýza mimo jiné ukazuje, že tuto krizi nemohou vyřešit jednoduchá opatření, nýbrž výchova lidí a pozvolná přeměna jejich smýšlení, životní orientace a způsobu jejich praktického jednání.

Je třeba reflektovat, že dnešní krize je nejen nějakým akademickým podnětem k přemýšlení, ale že je také zdrojem mnoha konkrétních, viditelných a velmi závažných společenských fenoménů, jež se daly do pohybu - a vůči nimž jsou naše vzdělávací politiky a školství jako takové v mnoha př́padech zcela slepé. Moderna - ruku v ruce s akcelerovaným vývojem vědy a technologií - přinesla během velmi krátké doby několika generací hlubokou proměnu reality našeho světa a způsobů našeho fungování v něm. Už polovina 20. století přitom přináší výstižné filozofické analýzy a reflexe krize moderního člověka, poukazuje na nebezpečí technokratizace, odtržení od př́rody a zdrojů humanity, na nebezpečí redukce člověka na kolečko v soukolí výrobních procesů. Moderna v umění byla odpovědí na tuto pocit'ovanou krizi a výzvou k hledání nové citlivosti a nových zdrojů porozumění sobě samému - a hledání nových „rájů srdce“ a osvobození. Postmoderna s globalizací přináší nové jevy - a také v mnohém jedovaté plody předešlého vývoje. Na globalizaci můžeme na jedné straně nahlížet jako na šanci na propojení lidstva a globální distribuci pozitivních výsledků technologického vývoje, na stranu druhou sledujeme - přes veškeré propojení - růst nových rozdílů, nových bariér a problémů. Svět nepřestal být „matením a motáním, kolotáním a lopotováním, mámením a šalbou, bídou a tesknosti“", dnešní člověk s poničenou lidskou přirozeností Boha ztratil a od světnice jeho srdce jej odvádí tisíc náhražek od konzumerismu, ničivého kultu dokonalosti, krásy a zdraví, přes mediální přesycení, proud sít’ových dat, do nichž je nutné být permanentně ponořen, až po svádivost otupujícího zábavního průmyslu nebo konspirací. Že je výsledkem „omrzení všeho a zoufáni", je nasnadě.

Dokážeme ale své „Srdce“ znovu najít? Ukazujeme tuto možnost generaci dětí, již vzděláváme a jež se rodí do světa plného hrozeb? Lze se divit tomu, že ve značné části společnosti rostou pocity zklamání a frustrace a že si žádají své vybití? Duchovní hlad po smyslu a touha po spravedlivém a smysluplném uspořádání věcí - ve spojení s potlačenou či náhražkovou, „instantní“ spiritualitou - přináší jen falešné mesiáše a nová zklamání, nikoliv pokoj, který Komenský vnímá jako ideální vyústění osobní cesty životem. Je zodpovědností nás pedagogů hledat a rozeznávat znamení a potřeby naší doby a čerpat z kořenů naší kultury to, co přetrvává a neztrácí hodnotu. Je třeba chápat vzdělávání a naše osobní, jedinečné edukační strategie jako odpověd' na pedagogickou interpretaci těchto znamení doby. 
Doufejme, že budeme schopni - podobně jako Jan Amos Komenský - ostrého vidění stavu světa a že budeme spolu s Komenským výchovu a vzdělávání vnímat jako akt „nápravy věcí lidských“. Právě tato Komenského vize nejenže nestárne, ale lze ji chápat jako trvalou součást naší živé - a žité - duchovní kultury. Tato duchovní kultura samozřejmě zanechává svůj otisk také ve vzdělávací politice a cílových orientacích školství. Ty zajisté podléhají proměnám v závislosti na vývoji společnosti a na tom, co je považováno za aktuální a potřebné. Odrážejí se v nich - vedle všeho aktuálního - také kořeny naší kultury, tradice, různé historicky podmíněné etické systémy a kulturní kontexty. Byt' se často vede skeptická debata o tom, že takto vyjádřený společenský ideál je pouhou utopií (někteří spíše vyžadují rychlé a konkrétní, dobře viditelné efekty), často si neuvědomujeme, že právě základní orientace a sdílené hodnoty jsou vlivnější, než se zdá. Formulované a sdílené představy, čeho se má za pomoci různých výchovných nástrojů dosáhnout, skutečnost mění již jen svým „tichým“ působením. Dávají škole, ale i učiteli-jednotlivci směr, vizi, dlouhodobou perspektivu. Edukace je v tomto pojetí ,aktivním, tvořivým výrazem starosti o člověka, aby se našel ve svém poslání, naplnil smysl života svého osobního i obecně lidského. Aby rozvinul svou osobnost, realizoval své potenciality“ (Helus, 2014, s. 16). Aby se stal plnou lidskou bytostí, již - jak je pevně přesvědčena tradice pedagogického i filozofického myšlení - nelze redukovat jen na některou z jejích mnoha rovin: člověk není pouze „lidským zdrojem“ pro konkurenceschopnost hospodářství, není ani pouhým konzumentem nebo občanem.

Jsme tělo a duše, vytváŕíme svět kultury a mravů, jsme částí prŕírody, a zároveň ji překračujeme (Pelcová, 2010, s. 238). Člověk má své racionální dispozice a lze jej definovat jako animal rationale, také je však imago Dei (obrazem Božím s duchovními dispozicemi a etickými výzvami, tolik podstatnými pro Komenského). Je zároveň Frischovým homo faber a zároveň komplikovanou bytostí vybavenou emocemi, intuicí, tvořivostí i iracionalitou. O všech těchto jeho tvářích nejlépe vypovídá umění a kultura, které - stejně jako výchova sama - plní úkol aktivizovat člověka a proces jeho sebeinterpretace.

Sama referenční oblast výtvarné výchovy, umělecké pole, s pojetím výchovy jako prostředku k porozumění věcem lidským a jejich „nápravě“ silně konvenuje. Podle Heluse (2014, s. 17 a 20) má toto cílové zaměření vést jednak $\mathrm{k}$ analýze panující krize (jež je podle něj především „krizí člověka, způsobu jeho života a jeho chápání hodnot“), jednak k ,edukaci obratu“, jež je odpovědí na „starost o člověka“ a koncepcí nápravy. V této pedagogické tradici se přitom v přímé návaznosti na Komenského akcentují různá hlediska od antropologických (týkajících se člověka, jeho kořenů a vývoje), přes etická (vědění nesmí být izolováno od etických otázek) a ekologická (v nejširším slova smyslu, tedy s akcentem na zodpovědnost člověka jako součásti širšího systému, v němž panují určité vztahy a jehož části se vzájemně ovlivňují) - až po zřetele transcendující (tedy přesahující ryze účelovou orientaci lidského života. Tato komplexita (dnes je pro nás důležitou výzvou, abychom ji vůbec uchovali) je př́mým dědictvím díla Jana Amose Komenského a snad i charakteristikou didaktického diskurzu výtvarné výchovy - at' již uvažujeme o vzdělávacím oboru na všeobecně vzdělávacích 
školách, o profesní přípravě profesionálů nebo o širokém poli neformálních vzdělávacích a kulturních aktivit.

Chceme-li poukázat na některé z množství inspirativních idejí Komenského a na jejich paralely s výzvami a aspekty současné výtvarné výchovy, lze to učinit mnoha různými způsoby. Lze hovořit o přímém vlivu, ale i o ,pouhé“ blízkosti idejí. Na každý pád je fascinující sledovat, jak Komenského teze - postulované před stovkami let - znějí aktuálně.

\section{Idea první: Hledání přirozenosti}

„Omnia sponte fluant, absit violentia rebus. | V̌se at’ plyne samo sebou, nebudiž věcem činěno násili.“.

„Přriroda nic netiskne ven, leč co uvnitř uzraje a samo chce vyrazit. Nebot' nenutí ptáčka opustit vejce, dokud se údy náležitě nevytvoři a nezesílí, ani ho nenutí k letu, dokud nevidí, že má peři, ani ho nevyhání z hnizda, dokud neuvidí, že umi létat, atd.“(J.A.K., Velká didaktika)

Komenský je všeobecně znám zejména díky tomu, jak výstižně a novátorsky rozpracoval základní didaktické principy - jež jsou stále platné a patři k univerzálně uznávaným pedagogickým zásadám. Kromě zásady názornosti, systematičnosti a dalších zmíníme na prvním místě neobyčejně důležitý princip přiměřenosti a ohledu k přirozenosti dětí. Komenský si uvědomoval (bez opory v tehdejší praxi, jež daný princip neuplatňovala), že je třeba zohledňovat věkové a individuální zvláštnosti dětí, že každé dítě má nejen věkové zvláštnosti plynoucí z prrirozenosti člověka a jeho psychického a tělesného vývoje, ale i určité potřeby a individuální charakteristiky. Komenský považoval za zásadní přihlížet $\mathrm{k}$ jedinečnosti každého žáka a vybízel $\mathrm{k}$ individualizaci výuky.

„V̌̌e at’ plyne samosebou, nebudiž věcem činěno násili“، (J.A.K., O nápravě věcí lidských, porady obecné): náš obor založený na výtvarném projevu jedince čekal až do 20. století, než porozuměl této zásadě, aplikoval ji do praxe a přestal pohlížet na dětský výtvarný projev jako na nedokonalý, chybný, jako na něco, co vyžaduje korekci a dril vedoucí k uspokojivému a ovšemže nepřirozenému - výsledku. Dnes si nelze výtvarnou výchovu představit bez respektu $\mathrm{k}$ přirozenosti dětského uvažování, $\mathrm{k}$ jejich přirozeným receptivním a expresivním zvláštnostem. Bez nadsázky lze cestu, již náš obor až do dneška urazil, charakterizovat jako hledání této přirozenosti a vedle toho také potřebné pedagogické rovnováhy mezi Scyllou vypjaté antipedagogiky (,,je správné nechat dítě tak, jak je“) a Charybdou nadměrných a necitlivých, mocenských zásahů do vývoje dítěte (,je pedagogickým úkolem na dítě působit, ovlivňovat je a měnit“). Je výzvou nechat vývoj uměleckého projevu žáka plynout přirozeně, vycházet z jeho zkušeností a zároveň jej citlivě pedagogicky doprovázet, rozvíjet, zasvěcovat do kulturních kontextů a učit jej novým dovednostem. 


\section{Idea druhá: Všestrannost rozvoje}

„Jestli rozum vymustruje se $k$ moudrosti, jazyk $k$ výmluvnosti, ruce $k$ důmyslnému dílu života konání; tot' bude ta sůl života, totiž moudrým býti, činiti, mluviti.“ (J.A.K., Orbis sensualium pictus)

Obor výtvarná výchova, v souladu se svou mateřskou disciplínou, uměleckým polem, zakládá svou jedinečnost a podstatu na tvưrčí činnosti člověka, při níž je pomocí různých typů vizuálních, verbálních, prostorových, zvukových či audiovizuálních (intermediálních) prostředků komunikován určitý kulturní obsah. Tento obsah sdílený skrze artefakt může mít podobu reálně existujících jevů, ale i subjektivně proživaných událostí, abstraktních idejí či vyšších emocí, citových vztahů, tělesných pocitů. Může se týkat vážných archetypálních, existenciálních konceptů, stejně jako humorných či paradoxních stránek lidského života; obsah může být vystavěn na nonsensu, může jím být meditace nad samotnou čistou formou. Při umělecké činnosti se přitom mohou uplatňovat zcela odlišné druhy činnosti: náročná intelektuální práce, fyzická činnost, ale i hra a experiment. Tak také úlohy ve výtvarné výchově stavějí na kognitivních procesech, ale i na intuici, tvořivosti, stejně jako na rozvoji schopností a různých praktických dovedností. Idea všestrannosti rozvoje, vyjádřená v Komenského díle Orbis sensualium pictus, výstižně vyjadřuje to, co náš obor svou letitou praxí i mnoha hraničními experimenty ověřil: totiž že všechny dané polohy mají svou cenu a že každý žák by měl pokud možno okusit všechny - a že nelze vzdělávání redukovat jen na rozvoj kognitivních funkcí a znalostí.

\section{Idea třetí: Škola hrou}

Schola Ludus | Škola hrou

Hra je přirozenou činností, během které se učíme mnoho podstatného. Je to královská cesta, kterou se žáci mohou přirozeně a s chutí rozvíjet ve všech aspektech podstatných nejen pro náš obor: po fyzické i intelektuální stránce, po stránce emocionální i sociální. Hra může rozvíjet senzorické a senzomotorické dovednosti, dovednosti v oblasti komunikace, schopnost exprese a vytváření významově obsažných metafor, morální dovednosti, návyky, postoje, jedinečné vlastnosti a nadání jedince - a samožrejmě oborové kompetence k umělecké komunikaci. V našem oboru pracujeme zejména s hrou výtvarnou, s výtvarným experimentem, při němž je dovoleno chybovat, při němž se objevuje něco nového a pracuje zde hlava ve spojení se smysly, rukou a tělem. Hra je pro žáky výzvou, pozváním, staví na experimentu, tvořivosti, divergenci, asociativnosti, imaginaci, tvořivém přístupu $\mathrm{k}$ obrazu. Během hry je žádoucí objevování a kladení nových otázek, na něž se v bezpečném prostoru hry pokoušíme odpovídat.

Je to specifická cesta rozvoje, při níž je důležité spojení myšlení, řeči, akce, činnosti rukou a mnohdy i celého těla. Hra nastoluje zdravé a přátelské klima, v němž je možné se radovat, navazovat a udržovat př́telství. Hravý př́istup $\mathrm{k}$ výuce paradoxně nastavuje mnohdy i velmi 
náročné a třeba i vážné situace, které však v rámci hry nejsou tíživé nebo stresující. Učíme se hledat řešení a tvưrčím způsobem přistupovat $\mathrm{k}$ lidem i ke světu okolo nás.

\section{Idea čtvrtá: Učení se prostřednictvím věcí a činností}

„Tedy slovům at' se vyučuje a uči jenom ve spojení s věcmi, tak jako se prodává, kupuje a přenáši víno s nádobou, meč s pochvou, dřevo s kůrou, ovoce se slupkou. Nebot' co jiného jsou slova než obaly a pochvy věcí?" (J.A.K., Velká didaktika)

Také Komenského výzva $\mathrm{k}$ učení se prostřednictvím věcí a činností - a nejen pomocí pojmových schémat, patří $\mathrm{k}$ zásadám, jež dlouho čekaly na své naplnění. Současné poznatky pedagogiky, vývojové psychologie, stejně jako psychologie učení potvrzují, jak zásadní je aplikace této pedagogické zásady či strategie. Ve výtvarné výchově, ale i v muzejní a galerijní edukaci na jejím dodržování stojí úspěch a kvalita výuky, at' již uvažujeme o objektovém učení, nebo o receptivních a expresivních aktivitách založených na obrazu nebo prostorovém artefaktu.

Práce s bezprostřední smyslovou skutečností, zakoušení ,jsoucna“ věcí, kvalit jejich materiality, to vše je ve výtvarné výchově naprosto zásadní. Právě věc sama o sobě, nikoliv její slovní popis, nám naplno otevírá a nabízí trsy významů, souvislosti, zkrátka obsah ve smyslu toho, co je objektem žákova poznání. Tento obsah nám otevírá právě naše interakce s artefaktem a poté navazující intelektuální a tvưrčí aktivita, stejně jako interakce s ostatními a vůbec všechny okolní podněty. Ve věci je komplexita, v činnosti se může vynořit hodnotný obsah a skrze hluboce prožitou smyslovou zkušenost zůstává a neuniká.

\section{Idea pátá: Význam obrazu ve vzdělávání | klíčová role vizuality}

Orbis sensualium pictus | Svět v obrazech

Komenský v řadě svých učebnic zcela objevně stavěl na vizualitě a na propojení pojmů a obsahů s obrazem. Nejlepším př́kladem - vpravdě novátorským a geniálním - je Komenského Orbis sensualium pictus. Text Brány jazyků otevřené je tady ilustrován, doplněn o obrazovou složku tak, že slovu / pojmu odpovídá jeho př́islušná vizualizace.

Náš obor je na vizualitě přímo založen a snažíme se v něm rozvíjet všemožné způsoby využití obrazových (nejen uměleckých) podnětů ve vzdělávání. Obrazem se učíme, skrze obraz poznáváme svět a učíme se chápat jeho složitost. Že je dnes vizualita naprosto klíčová, netřeba zdůrazňovat. To, co je podstatné, je ale také pěstování schopnosti interpretování obrazů a reflexe nástrojů vizuality a způsobů tvorby vizuálních metafor - at' již sémanticky náročných, nebo banálních či těch na bázi dnes virálních obrazových memů a apropriací.

Komenský hluboko v minulosti, kdy tento typ vizuality ještě nebyl vůbec představitelný, akcentoval smyslové poznávání předkládaného vzdělávacího obsahu; obraz mu byl nejen názorným doplňkem, ilustrací, ale i sdělným významovým celkem. Právě tuto rovinu také 
dnes rozvíjíme, obraz vnímáme jako komplex, hovoříme o myšlení obrazem, svědčíme o nezaměnitelném vědění o skutečnosti, jež je vlastní pouze obrazové komunikaci.

\section{Idea šestá: Jazyk jako vyjádření obsahu}

„Kolik kdo rozumí, tolik at' zvyká vyjadřovat, a naopak, co pronáší, tomu at’ se uči rozumèt. Nikomu nebudiž dovoleno odřikávat, čemu nerozumi nebo nedovede vyložit. Nebot' kdo nedovede vyjádřit, co myslí, je němá socha; kdo tlachá, čemu nerozuměl, je papoušek.“ (J.A.K., Velká didaktika)

Jazyk je branou i hranicí našeho myšlení, a jak vystihl Wittgenstein, za hranicemi jazyka lze jen mlčet. Komenský věnoval jazyku zvláštní pozornost, jak dokládá např. půvabná ukázka z jeho Scholy Ludus, v níž učitel na otázku žáka, co je to být moudrým, odpovídá takto: „Všemu, co je potřebné, dobře rozumět, všecko dobře konat, dobře vyjadřovat. “ A o pár řádků dál dodává: „Především se musiš naučit jednoduchým zvukưm, z nichž se skládá lidská řeč, které dovedou vydávat živočichové, a které tvůj jazyk umi napodobovat a tvá ruka může malovat. Potom pưjdeme do světa a budeme pozorovat všecky věci.“ (J.A.K., Schola Ludus)

V našem oboru někdy bývá role jazyka upozad'ována, protože pracujeme primárně s mimoverbálními projevy. Bez uchopení těchto projevů do jazyka se ale často nerozvine celý vzdělávací potenciál uměleckého osvojování světa. Uchopení „obrazu“ a vůbec celého expresivního procesu slovy a jeho analyzování samozřejmě zakládá jistou redukci, na druhou stranu rezignace na uchopení jazykem zakládá riziko nerozpoznání obsahu, který může protéct mezi prsty výtvarného prožitku. Je třeba spojovat obojí: jazyk a ruku.

\section{Idea sedmá a hlavní: Transcendence}

„... potřebných věcí neznaji, poněvadž se uči věcem nepotřebným.“ (J.A.K., Škola vševědná, s. 5)

Jak už bylo zdůrazněno v úvodu článku, Komenského pedagogický systém nepochopíme bez jeho duchovní podstaty. Komenský - to zdaleka nejsou jen bystré postřehy o učení, praktické zásady a geniální učebnice, ale především koncepce životní cesty jedince hluboko zakotvená ve filosofii a teologii, stejně jako v náboženské praxi vztahování všech aspektů života k Bohu, praxe modlitby a žitého kultu.

Komenský nám zanechal apel, abychom výchovou léčili důsledky archetypálního pádu člověka a obnovili vztah s tím, z nějž plyne „veškeré dýchání i život sám“ (Komenský, 1920). Komenský nám ukazuje cestu k spirituální podstatě lidství, výzvu k duchovnímu naplnění, bez nějž nenajdeme pokoje, k nepodstatnějšímu horizontu naší pozemské pouti, a tím i ke křest'anské humanitě uplatňované dnes a tady.

V umění nacházíme vyjádření stejných kulturních obsahů, a to dokonce i v období moderny, jež bývá označována za dobu, která Boha odvrhla. Moderní odmítnutí náboženských tradic 
a univerzálního náboženského rámce nám sice přineslo vysokou míru osobní zodpovědnosti, autonomii a svobodu, nikoliv však upokojení a očekávanou „osvobozenou“ humanitu. Situaci vystihl Chesterton svým známým bonmotem, který rríká, že jakmile člověk přestane věřit v Boha, je ochoten uvěřit úplně všemu. Modernu i období po ní lze skutečně vnímat jako vládu idolatrie, jež se vyznačuje zplaněním a povrchností spirituality, vzýváním bůžků v podobě konzumu, módy, těla, dokonalosti, pokroku. Moderna nepřinesla jen opojení svobodou a pozitivní plody v podobě technologického pokroku nebo citlivosti vůči jednotlivci a jeho právům a potřebám, přinesla rovněž existenciální tíseň, nezodpovězené otázky po podstatě lidství, obavy ze ztráty humanity, z odlidštění společnosti, z její př́lišné technokratizace, z okleštění podstatných dimenzí člověka.

A zde je také nejpodstatnější spojení mezi tímto aspektem Komenského odkazu a nejhlubší, často nevyslovovanou bází našeho oboru výtvarná výchova. Naším úkolem je z této báze čerpat a otevírat $\mathrm{s}$ žáky také tato témata. $\mathrm{O}$ vzdělání se občas mluví jako o něčem, co nám zůstane, když zapomeneme fakta a naučené informace. Co ale zůstane, když ztratíme i to? Každý člověk nepochybně zakouší situace, kdy potřebuje ještě jiné vzdělání: povědomí o smyslu, o cestách ke spirituální dimenzi člověka, povědomí o existenci „ráje srdce“ a o tom, že je blahodárné do něj vstupovat.

\section{Literatura}

HELUS, Zdeněk, 2014. Edukace jako projev starosti o člověka: Příspěvek k osobnostně rozvíjejícímu pojetí výchovy. In: JEDLIČKA, Richard \& HELUS, Zdeněk. Teorie výchovy tradice, současnost, perspektivy. Praha: Karolinum, s. 13-34. ISBN 978-80-246-2412-9.

KOMENSKÝ, Jan Amos, 1845. Joan. Amos. Comenii Orbis pictus $=$ Swět $w$ obrazích $=$ Die Welt in Bildern = Le monde en tableaux. Praha: Tisk a sklad Jaroslawa Pospíšila. $144 \mathrm{~s}$. KOMENSKÝ, Jan Amos, 1888. Des Johann Amos Comenius Schola Ludus d. i. Die Schule als Spiel. Langensalza: Hermann Beyer \& Söhne. xvi, 373 s. Bibliothek Pädagogischer Klassiker.

KOMENSKÝ, Jan Amos, 1888. Jana Amosa Komenského Sebrané spisy vychovatelské. III, O nápravě věci lidských, porady obecné. Část prvá, Panegersia, povzbuzení obecné... Přerov: Fr. Bayer. 318 s. Bibliotéka paedagogických klassikův českých i cizích; dílo 8.

KOMENSKÝ, Jan Amos, 1920. Hlubina bezpečnosti. Praha: Kvasnička a Hampl. 146 s.

KOMENSKÝ, Jan Amos, 1930. Jana Amosa Komenského Didaktika velká. Vyd. 2. Praha: Dědictví Komenského. 314 s. Vybrané spisy J. A. Komenského; díl 1.

KOMENSKÝ, Jan Amos, 1960. Škola vševědná. In: Vybrané spisy Jana Amose Komenského, svazek II. Praha: Státní pedagogické nakladatelství.

PELCOVÁ, Naděžda, 2010. Vzorce lidství: filosofické základy pedagogické antropologie. Praha: Portál. 261 s. ISBN 978-80-7367-756-5. 